\title{
Sports Facilities - Analyses and New Trends
}

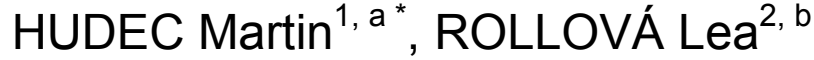 \\ ${ }^{1,2}$ Fakulta architektúry STU, Námestie Slobody 19, 812 45, Bratislava 1 \\ a1martin_hudec@stuba.sk, ${ }^{b}$ lea.rollova@stuba.sk
}

Keywords: Sports Buildings, Architecture, Hybrids.

\begin{abstract}
The possibility to carry out sports activities is one of the factors which increase the quality of life for the citizens of a city. The city of Bratislava ranks among the biggest places of sport activities in Slovakia. Most of the sport facilities were, however, built in the past century; therefore they do not fulfill the demands of technical condition, economic efficiency, do not meet the international criteria of professional sport and do not meet the broad spectrum of the modern sport activities, especially for the younger age group users. It is needed to modernize and build the new sport buildings in all areas of sport, at school sports, sport for all and also in professional and performance sport activities. In accordance with the new trends in design of sports facilities, there is a need to reduce servicing costs, to improve implementation of technologies that increase the quality, safety and economy efficiency. The priority is the creation of multifunctional or hybrid facilities, which can offer the widest range of activities to users. In this report, the survey of the condition of existing sports facilities in Bratislava and proposal for possible solutions to the revitalization or the design of new facilities with sport function is published. The combinations of different activities which are compatible and suitable for multifunctional facilities are also published here.
\end{abstract}

\section{Introduction}

The transformation of sport in Slovakia was launched in 2004, which was mostly affected by The Project of decentralization of the state administration, what results into changes in the ambit of sport management at all levels. In the document Conception of Development of Physical Culture in the City of Bratislava for the Years 2009 - 2015, the main objective is to create better conditions for school, recreational, performance as well as professional sport, focusing on the support of general public sports activities. For the reason of the direct channeling funds for construction and renewal of sports facilities, in 2008, The Sport and Recreation Territorial Master Plan of the City of Bratislava was drawn. It suggests spatial development of functional areas of sport and recreation, set in the Land Use Plan of City of Bratislava. Currently, the municipality focuses primarily on the implementation of bicycle paths, but also develops activities related to the construction and renewal of sports facilities. As the issue of sports facilities is very broad, therefore this contribution focuses on the current conditions of facilities in Bratislava and the issues related to the modernization and design of new facilities.

Sports Facilities in Bratislava. Most sports facilities in Bratislava were constructed in the last century and currently do not meet the requirements in terms of technical condition, economic efficiency, their parameters do not meet current criteria for professional sport or do not meet of the required range of modern sporting activities, especially for the younger age categories of users and the disabled athletes. Options to do sports activities in Bratislava are determined by the amount of sports venues per population (about 430,000 inhabitants). Unfavorable situation in the material and technical provision of sport affects the stagnation in some forms of sport, as well as causes a decline in the sport in Bratislava. Shortcomings exist in all areas of sport, school physical education; sport for all and also on performance and professional sport levels. Types and number of sports facilities and venues, regardless of their owner, are inadequate and not in line with the needs of the sports industries which have a long tradition and results in Bratislava. Over the last 10 years some sports 
facilities of national importance have been built. The construction of these facilities is for the development of competitive sports in Bratislava beneficial, but one can argue if at least some of them should be designed as multi-purpose ones, which would be more efficient considering the amount of invested funds.

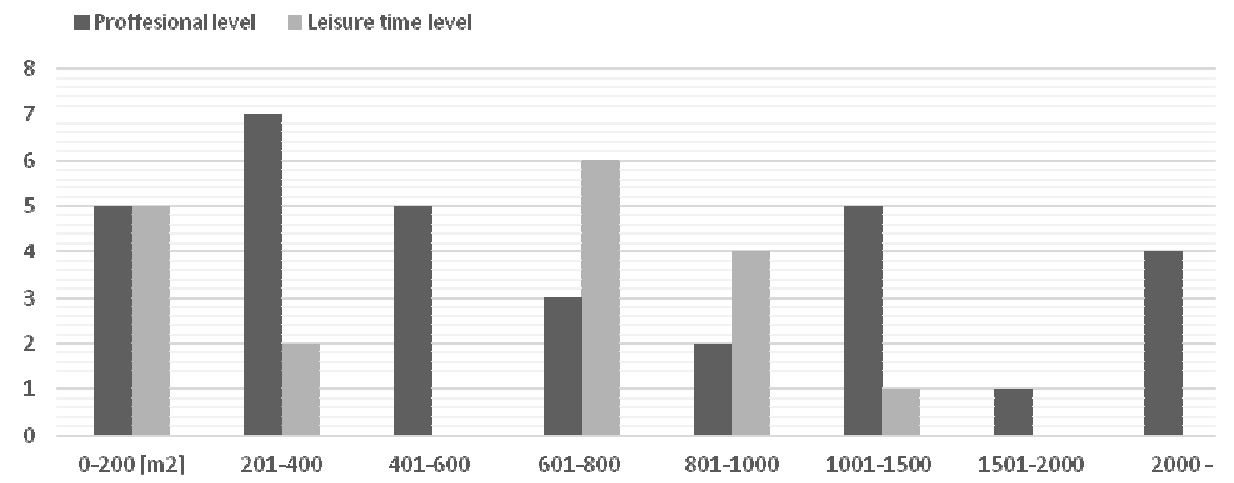

Fig. 1. Number of Sport Halls in Bratislava (y axis) and their total area (x axis).

The Land Use Plan of Bratislava, in the section referring to sports, physical exercise and leisure time states that "Bratislava as the capital city of Slovakia has a lack of sports and physical education facilities. The capital meets only about $62 \%$ of the required land area of physical education and sports facilities per 1 inhabitant. Deficits in sports and recreational facilities are typical for all districts except for Nové Mesto."[1] The largest deficit in sports areas is in the Staré Mesto, Lamač, Dúbravka, Devínska Nová Ves a Karlová Ves. In The Land Use Plan is the development of sport and physical education and sports activities designed by stabilization and completion of existing sites and facilities as well as by proposals for new areas for sport and physical education facilities in developing areas of the city. The lack of opportunities for sports is supported by the decrease in number of sports grounds and facilities, reduction of sports clubs or units and also by decrease in the number of sporting events. Some smaller private services such as spas, fitness centers, squash, or smaller pools within public buildings partly compensate the needs of citizens, many of them are costly and thus unavailable for the underprivileged parts of the population. The main reason for the loss of sports grounds is inefficient operation of sports facilities and the lack of state subsidies for the development of sport. The research is therefore aimed at finding suitable combinations of sports activities with other types of leisure time activities that are "perfect-fit" for residents of different districts of a city.

Recommendations and Solutions in Proposal of Sports Facilities. Respecting the changes and increases in the importance of sport in society, the more acute the concept of integration and hybridization of sports facilities becomes, i.e. merging sports activities with other functions. In parallel with the change in the system of values there is also an increasing need for quality for leisure time activities and active recreation. Reasons for integration and hybridization of these facilities are mostly of an economic character. Merging sports activities with other functions (cultural, social, business or with temporary accommodation, etc..) can be achieved by reduction of operating costs, whereas in the case of irregular use of mono-functional sports facilities operating costs are disproportionately high and return on investment is worse. Integration is not a new trend, is has been noticeable since the mid- last century, when the sporting activities merged with schools, hotels, colleges, administrative or residential buildings. Hybridization in the context of developing sports facilities, is viewed as a response to a change in lifestyle as well as the city, to the economic factors affecting land prices. Hybrid sports facilities represent a typological fusion of different kinds of programs that are able to operate independently. The positive result of the hybrid concept of new design or renewal of sports facilities is an object used throughout the day ("full-time building" [2]). It is a common requirement to improve the availability of sports facilities in the central zones of urban structure. The city must offer adequate spaces, or land for developing new types of sports, which applies to both recreational sports area and professional sport. The lack of state funds can be 
saturated by private sector investments, which can promote the development of the spectrum of sports activities. New designs of sports facilities must meet economic, security and technology requirements. Reflecting the needs of the residents of the city and in combination with appropriate typological programs, one can create a favorable basis for high-quality, sustainable development of sport in Bratislava.

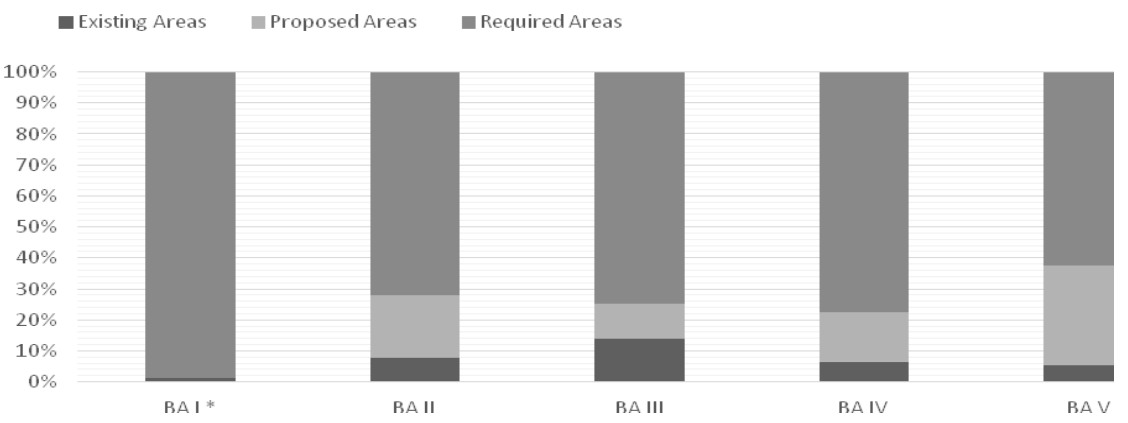

Fig. 2. Ratio of Existing, Proposed and Required Areas of Leisure Time Sports in Bratislava.

* District Bratislava I. covers historical centre of town and no free space remains for building new sports facilities or hybrid buildings.

Survey. To find out real demands of Bratislava residents for leisure time in the form of sports or other activities, a marketing survey in the form of questionnaires and interviews was carried out. The aim of the survey was to monitor the general requirements of inhabitants for the availability of sports and other leisure facilities in the city district, as well as to find appropriate combination of new designed multi-functional use or hybrid objects [Figure 3, 4, 5]. The survey involved 742 inhabitants of Bratislava. A comparison of the analysis of the facts of sports facilities with requirements of inhabitants incurred basis for design options of new buildings for each district of Bratislava, which would reflect the population demand.

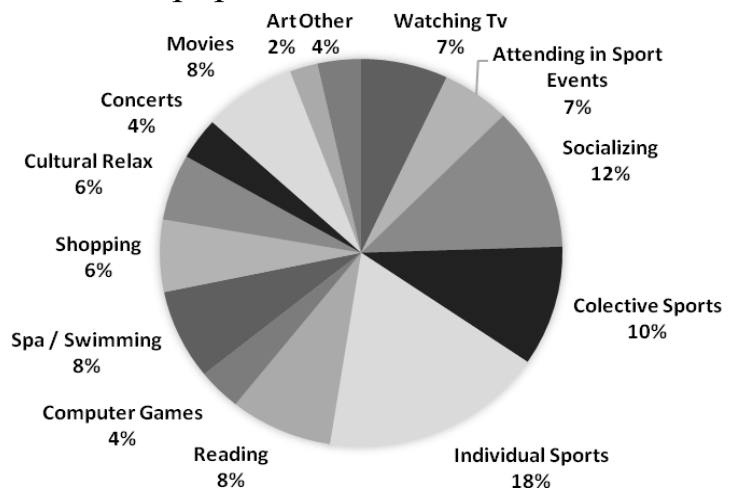

Fig. 3. Ratio of Residents Requirements for Leisure Time Activities in Bratislava.
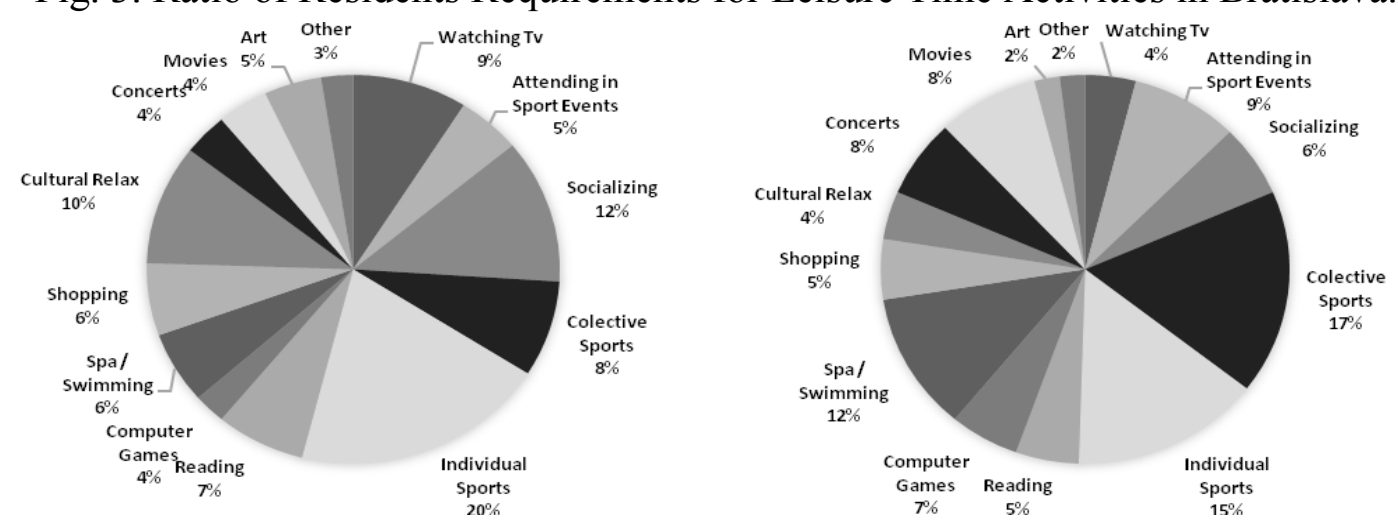

Fig. 4, 5. Ratio of Resident Requirements for Leisure Time Activities in Bratislava Districts.

(Figure 4 - Bratislava II., Figure 5 - Bratislava V.) 
The analysis of the research showed that the demands of citizens for different areas of sports are differentiated depending on the current offer of sports activities, on the age structure and gender of respondents. In evaluating sport activities based on the age the following facts were found:

1. Young respondents aged under 20, prefer team sports which are related to the game and competition, mostly football, basketball or floorball.

2. Adults 20 to 50 years preferred individual sports related to increasing fitness - fitness, running, cycling, female aerobic,

3. Middle aged respondents 40-60 years preferred sports activities related to increasing health fitness - gymnastics, swimming, cycling or walking

4. In the old age, the over 60 s performed less difficult sports activities - walking, tourism, swimming.

In the evaluating the demand for leisure activities in the city districts, differences were found mainly related to the age structure of respondents and to current offer of services. For example, in the district of Bratislava II., where there is more accumulation of higher age groups, there was a demand for cultural activities, or activities of social character and a demand for facilities or venues to perform individual sports activities was dominating. The district of Bratislava $\mathrm{V}$, where there is a higher percentage of young people, had generally a higher demand for sporting activities, for example team sports and swimming, because in this part of city there is not any swimming pool facility. The analyses carried out in selected urban areas further showed that from a commercial point of demand the combinations of these typologies in integrated facilities are suitable:

For the district Bratislava II - cultural events, public spaces, individual sports, business and the district Bratislava V - collective and individual sports, swimming pool, cinema, commercial spaces, culture. The next stage of the research will continue further specification of the ratio of each type of activities.

\section{Conclusion}

The method of design and locating new sports facilities, with regard to the survey, from the earliest phases, should have considered the aimed range of services so that the facility was popular and therefore cost-effective. In developing leisure facilities one must also reckon on the changing requirements of the residents, therefore the architectural concept of new facility must be adaptable. Taking these factors into account, it is possible to achieve social sustainability and economic profitability, which is a prerequisite for the healthy development of sports at each level.

\section{References}

[1] Územný plán hlavného mesta SR Bratislavy, Bratislava, 2007.

[2] J. Mozas et al, A Historical Overview, in: Hybrids II, a+t ediciones, Vitoria-Gasteiz, 2008.

[3] L. Rollová, Športové stavby v Bratislave: Analýza existujúceho stavu a odporúčania na doplnenie športovej vybavenosti, ŠOV BA 2012 Občianska vybavenost' Bratislavy - problémy a perspektívy európskej metropoly, STU, Bratislava, 2012.

[4] D. Končeková, A. Schleicher, Športovo relaxačný areál Bratislava - Krčace: Alternatívne riešenia. ŠOV BA 2012 Občianska vybavenost' Bratislavy - problémy a perspektívy európskej metropoly, STU, Bratislava, 2012. 